\title{
EISCAT observations of plasma patches at sub-auroral cusp latitudes
}

\author{
J. Moen ${ }^{1, *}$, H. C. Carlson ${ }^{2}$, K. Oksavik ${ }^{3}$, C. P. Nielsen ${ }^{4}$, S. E. Pryse ${ }^{5}$, H. R. Middleton ${ }^{5}$, I. W. McCrea ${ }^{6}$, and P. Gallop ${ }^{6}$ \\ ${ }^{1}$ Department of Physics, University of Oslo, Norway \\ ${ }^{2}$ Air Force Research Laboratory, Air Force Office of Scientific Research, Arlington, Virginia, USA \\ ${ }^{3}$ The Johns Hopkins University Applied Physics Laboratory, Laurel, Maryland, USA \\ ${ }^{4}$ Norwegian Polar Institute, Ny-Aalesund, Norway \\ ${ }^{5}$ Institute of Mathematical and Physical Sciences, University of Wales, Aberystwyth, SY23 3BZ, UK \\ ${ }^{6}$ Rutherford Appleton Laboratory, Chilton, Didcot, OX11 0QX, UK \\ *also at: Arctic Geophysics, The University Centre in Svalbard, Longyearbyen, Norway
}

Received: 30 November 2005 - Revised: 22 March 2006 - Accepted: 26 April 2006 - Published: 20 September 2006

Part of Special Issue "Twelfth EISCAT International Workshop"

\begin{abstract}
A sequence of 3 patches of high-density $\left(10^{12} \mathrm{~m}^{-3}\right)$ cold plasma on a horizontal scale-size of 300$700 \mathrm{~km}$ was observed near magnetic noon by the EISCAT VHF radar above Svalbard on 17 December 2001. The patches followed a trajectory towards the cusp inflow region. The combination of radar and all-sky observations demonstrates that the patches must have been segmented equatorward of the cusp/cleft auroral display, and hence their properties had not yet been influenced by cusp particle showers and electrodynamics on open flux tubes. The last patch in the sequence was intersected by radio tomography observations, and was found to be located adjacent to a broader region of the same high electron density further south. The patches occurred under moderately active conditions $(\mathrm{Kp}=3)$ and the total electron content (TEC) of the high-density plasma was 45 TEC units. The train of patches appeared as a segmentation of the tongue of ionization. The sequence of patches occurred in association with a sequence of flow bursts in the dusk cell return flow. It is proposed that reconnection driven pulsed convection is able to create sub-auroral patches in the region where high density mid-latitude plasma is diverted poleward toward the cusp. It is the downward Birkeland current sheet located at the equatorward boundary of the flow disturbance that represents the actual cutting mechanism.
\end{abstract}

Keywords. Ionosphere (Auroral ionosphere; Electric fields and currents; Polar ionosphere)

\footnotetext{
Correspondence to: J. Moen

(jmoen@fys.uio.no)
}

\section{Introduction}

Crowley (1996) defined polar cap patches as islands of high density ionospheric plasma surrounded by plasma of half the density or less. After formation by ionospheric cusp dynamics, the patches follow the convection pattern across the pole from day to night and are pulled into the nightside oval on exiting the polar cap (Buchau et al., 1983; Weber et al., 1984; Lorentzen et al., 2004). Several observation techniques have been used for patch studies, such as direct electron density measurements by ionosonde (Buchau et al., 1983; Dandekar and Bullett, 1999; Dandekar, 2002), incoherent scatter radar (e.g. Valladares et al., 1994, 1996, 1998; Carlson et al., 2002, 2004, 2006; Lockwood and Carlson, 1992; Lockwood et al., 2005a, 2005b; Oksavik et al., 2006a), and ionospheric tomography (Walker et al., 1999; Pryse et al., 2004), 630.0-nm airglow intensity that is proportional to electron density (Weber et al., 1984; McEwen and Harris, 1995, 1996; McEwen et al., 1995, 2004; Lorentzen et al., 2004), and more indirectly by HF coherent scatter radars of the SuperDARN network (Rodger et al., 1994; Ogawa et al., 1998; Rodger and Graham, 1996; Milan et al., 2002, 2005; Oksavik et al., 2006a). The latter technique does not provide a measurement of the electron density but gives the backscatter power from irregularities on electron density gradient associated $\boldsymbol{E} \times \boldsymbol{B}$ drift instability (Tsunoda, 1988; Chaturvedi and Ossakow, 1981). The SuperDARN network has the advantage of large spatial coverage and high temporal resolution, and also the possibility for conjugate measurements in the Northern and Southern Hemispheres (Rodger et al., 1994).

Electron density patches and associated density gradients give rise to disturbances on HF radio communication links in polar regions and may under extreme conditions give rise

Published by Copernicus GmbH on behalf of the European Geosciences Union. 
to an inaccuracy or loss of signals in satellite navigation and communication systems. It is important to know when and where these extreme situations may occur. The main focus with regards to the plasma structure has been the formation of polar cap patches in the cusp inflow region. It was recognized at an early stage that mid-latitude ionospheric plasma produced by solar EUV provided a viable reservoir of source plasma for polar cap patches, with the plasma being drawn by convection into the polar cap in a tongue of ionization. The tongue of ionization is usually thought of as a homogenous stream of plasma that follows the convection streamlines of the afternoon cell into the cusp region, and hence is a potential source for polar cap ionospheric patches. Using measurements by the Chatanika incoherent scatter radar in Alaska, Foster (1984) mapped the average diurnal pattern of convection and the F-region density around the auroral oval. In the rest frame of the Earth he documented the stagnation in the plasma flow in the post-noon sector where solar EUV ionization is high before heading towards the cusp inflow region. He mapped the cusp convection throat to a longitudinally narrow region of 3-4 hours wide in MLT. In a series of papers Foster and coworkers documented the regular occurrence of high-TEC patches and plumes of ionization observed in the dusk sector immediately equatorward of the ionospheric trough, a phenomenon called storm enhanced density events (SEDs) (e.g. Foster, 1993; Foster et al., 2004a). Under disturbed conditions the presence of a sub-auroral electric field driven by tail dynamics speeds up high density plasma to move sunward. Foster et al. (2002) linked an SED event to structuring and drainage of the outer plasmasphere. The phenomenon of SEDs is by observation addressed to the American sector, but one should expect to see similar F-region dynamics in the European sector. Due to the Earth's dipole tilt relative to its rotational axis, SEDs will occur at higher geographic latitude in the European sector, and hence the electron density of this phenomenon is expected to be much lower than in the American sector.

The difficulty with patch segmentation is to explain the low density regions between patches (Lockwood et al., 2005b). The mechanisms that have been suggested to segment the intake of cold solar EUV ionized plasma into the cusp throat can be divided in three families:

- IMF regulation of the cusp convection pattern causing alternating intake of high and low density plasma (Anderson et al., 1988; Rodger et al., 1994; Milan et al., 2002).

- Plasma depletion within flow-burst channels due to enhanced recombination (Rodger et al., 1994; Sojka et al., 1993; Valladares et al., 1994; Pitout and Blelly, 2003; Pitout et al., 2004) associated with newly-opened magnetic flux tubes.

- Plasma structuring by transient reconnection where the open closed boundary (OCB) leaps equatorward to a re- gion of higher density plasma, followed by poleward relaxation of that boundary carrying with it the high density plasma accelerated into the polar flow (Lockwood and Carlson, 1992; Carlson et al., 2002, 2004, 2006).

In contrary to polar cap patches observed within the polar cap, the current paper reports on a sequence of patches at sub-auroral cusp latitudes, appearing as a segmentation of the tongue of ionization well equatorward of the auroral cusp on closed magnetic field lines. Localized density enhancements equatorward of the auroral cusp were reported by Pryse et al. (2004). Milan et al. (2002) presented patch structures in HF cusp backscatter interpreted as subauroral patches. In this paper we present a combination of observations by the EISCAT radar, all-sky camera and ionopsheric tomography, and as such provide the first documentation of plasma islands existing within the tongue of an ionization region, at subauroral latitudes.

\section{Observations}

ACE was situated at $(235,31,0) R_{E}$ in $(\mathrm{X}, \mathrm{Y}, \mathrm{Z}) \mathrm{GSM}$ coordinates. Solar wind plasma and IMF data from 06:00 to 09:00 UT are presented in Fig. 1. The solar wind speed was $\sim 500 \mathrm{kms}^{-1}$, on average, and the delay from ACE to the solar wind impact on the ionosphere was expected to be about $1 \mathrm{~h}$. Figure 1f presents a keogram for the $630.0 \mathrm{~nm}$ auroral emission recorded by the Ny-Ålesund Meridian Scanning Photometer $\left(78.9^{\circ} \mathrm{N}, 12.0^{\circ} \mathrm{E}, 76.0 \mathrm{MLAT}\right)$ from 07:00 to 10:00 UT. Note that the MSP time axis has been shifted $1 \mathrm{~h}$ forward relative to the ACE time axis. The keogram displays emission intensity versus scan angle $\left(15^{\circ}\right.$ north to $175^{\circ}$ south) and time. This paper will focus on plasma structures observed by EISCAT between 08:00-09:15 UT, and particular attention is therefore drawn to the ACE data from 07:00 to $08: 15$ UT. $B_{Y}$ was strong and positive all morning, except for an interval of $\sim 20$ min starting around 07:15 UT, when it suddenly went from $7 \mathrm{nT}$ to $-2.5 \mathrm{nT}$ in $2.5 \mathrm{~min}$. After a brief negative excursion, it hovered around zero until a sudden jump up to $3 \mathrm{nT}$ and then a gradual increase back to values exceeding $5 \mathrm{nT}$. The sharp, negative transition in $B_{Z}$ at $\sim 07: 10$ UT provides a suitable test on the timing. This is in alignment with a well-defined equatorward step in the cusp auroral boundary at 08:11 UT (marked by a red arrow), consistent with intensified magnetopause reconnection. The cusp aurora was very broad in latitudinal extent at this time, with simultaneous brightening at either side of zenith $\left(90^{\circ}\right.$ elevation), indicating simultaneous lobe and magnetopause reconnection associated with the $B_{Z}$ negative turning (Sandholt et al., 1998). This was followed by a sequence of the classical poleward moving auroral forms (Sandholt et al., 1990, 1993; Denig et al., 1993; Milan et al., 1999; Moen et al., 2001; Oksavik et al., 2004, 2005) attributed to pulsed magnetopause reconnection (Lockwood et al., 1998). 

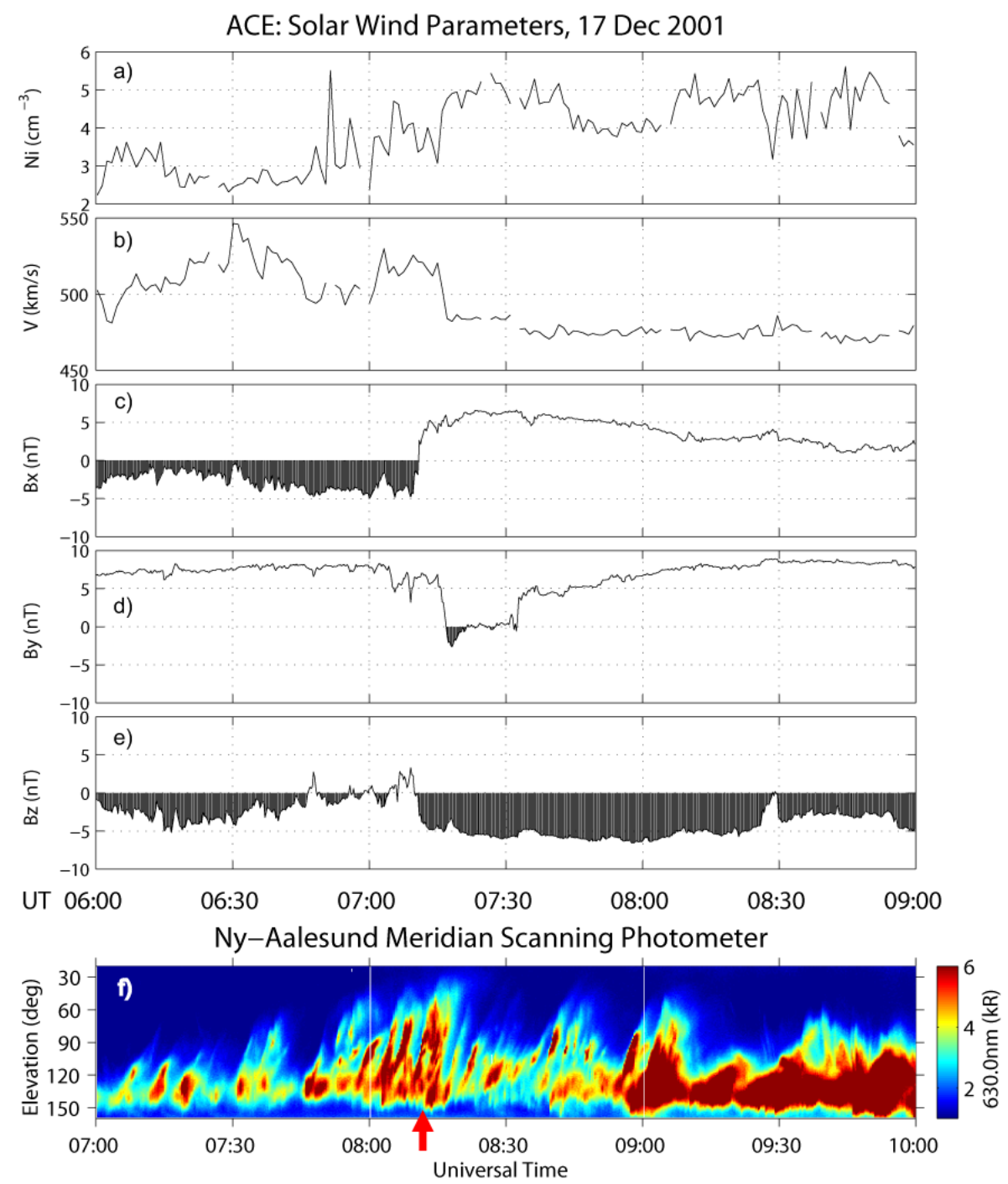

Fig. 1. Solar wind plasma and interplanetary magnetic field (IMF) data measured by ACE near the first Lagrange point from 06:00-09:00 UT (panels a-e), and a keogram of the 630.0-nm auroral emissions recorded by the Ny-Ålesund Meridian Scanning Photometer from 07:0010:00 UT (panel f). The magnetic field components are presented in GSM coordinates.

The EISCAT VHF radar was operated in a split-beam configuration at its lowest possible elevation $\left(30^{\circ}\right)$. The geometry is illustrated in the upper left frame of Fig. 3, which we will return to soon. The bore site beam (Beam 1) of the VHF radar was pointing towards geographic north, and Beam 2 pointed $12^{\circ}$ west of Beam 1 which is toward the magnetic pole. The data have been processed at a 1-min resolution. Figure 2a shows electron density measured along Beam 2 from 07:00-09:15 UT ( 10:1012:25 MLT), and Fig. 2b shows the corresponding observations from Beam 1. As indicated on the right-hand axis, over the latitude span from 70-75 MLAT, the height varied from $220 \mathrm{~km}$ to $600 \mathrm{~km}$. Figures $2 \mathrm{c}$ and $2 \mathrm{~d}$ show electron and ion temperatures from Beam 1, respectively. Figure 2e presents flow vectors obtained by combining line-of-sight ve- locities from corresponding MLAT positions along the two radar beams. This procedure assumes uniform plasma flow along L-shells, i.e. over a longitudinal distance increasing from $110 \mathrm{~km}$ at 70 MLAT to $280 \mathrm{~km}$ at 75 MLAT, which cannot always be expected true during local flow disturbances in the cusp. However, in Fig. 2e we see a predominant northwesterly oriented plasma flow, particularly strong poleward of 72.5 MLAT between 07:00-08:00 UT. Transient enhancements in $T_{i}$ (strong Joule heating) are also seen within this region. Beam 1 observed a band of enhanced electron density between 72-73 MLAT which represents the tongue of ionization. The equatorward boundary of this band migrated equatorward and the electron density within the band increased as time progressed. Beam 2 encountered the tongue of ionization at $\sim 07: 40$ UT. A sequence of poleward moving plasma 


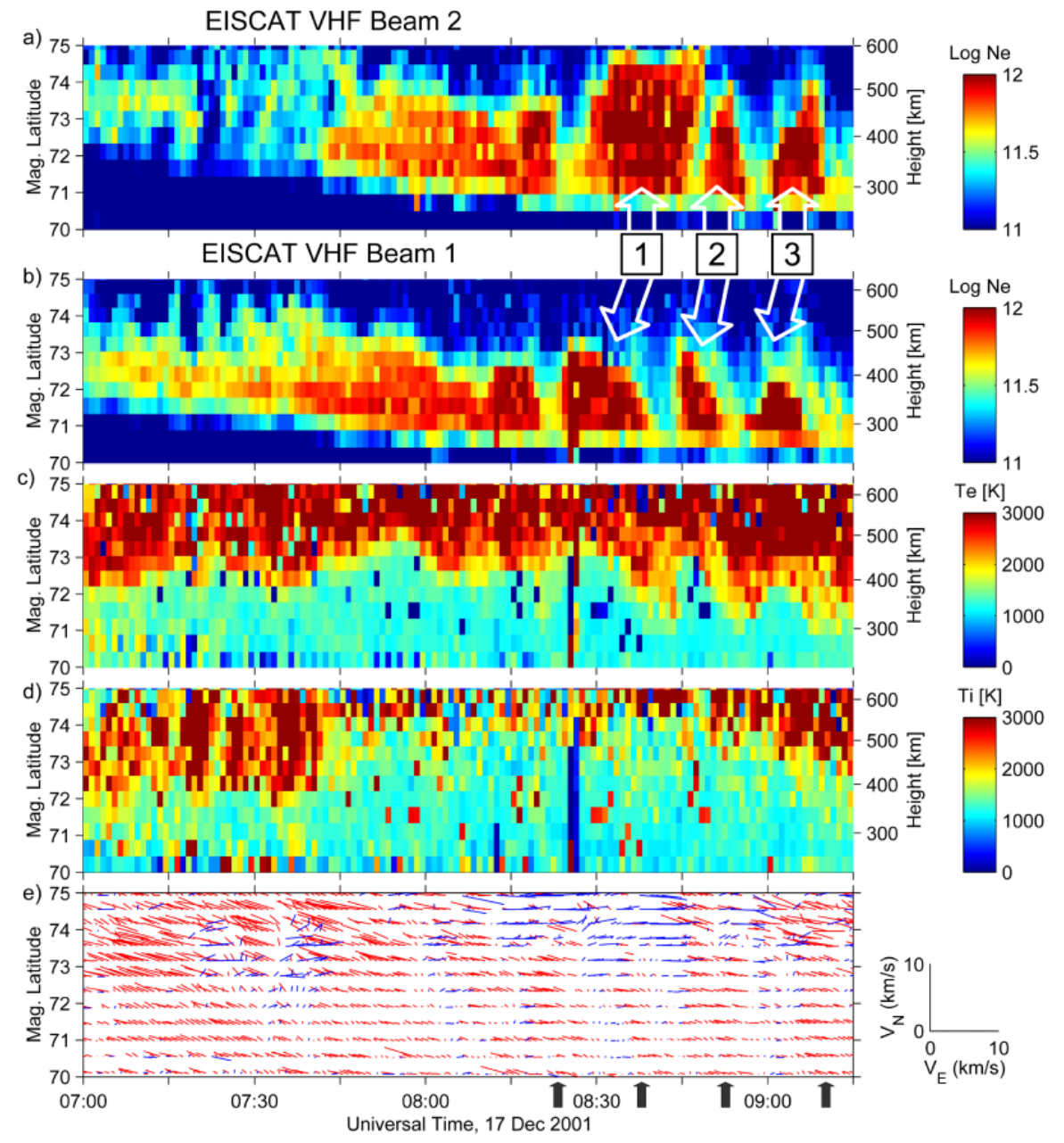

Fig. 2. Observations from the EISCAT VHF radar plotted versus magnetic latitude and time. Beam 1 was pointing $12^{\circ}$ east of Beam 2 , which was directed towards magnetic north. The data shown are: (a) electron density from Beam 2; (b) electron density from Beam 1; (c) electron temperature from Beam 1; (d) ion temperature from Beam 1; and (e) flow vectors derived by combining line-of-sight velocities from Beam 1 and Beam 2.

filaments were observed in both radar beams from 07:0007:40 UT. These patch forms are uniquely related to a corresponding sequence of poleward moving auroral forms seen from 07:00-07:40 UT in Fig. 1f. This time interval provides ample evidence for polar cap ionospheric patches being cut off from the tongue of ionization by transient reconnection, and the event sequence has been examined in detail by Carlson et al. (2006). They found the patch formation entirely consistent with the Lockwood and Carlson (1992) conceptual model which strictly relies on the open closed boundary (OBC) being located close to a gradient in solar EUV ionized plasma on the equatorward side. The current paper concentrates on the high-density $\left(\sim 10^{12} \mathrm{~m}^{-3}\right)$ plasma structures that have formed well equatorward of the cusp auroral boundary. In Beam 1, the electron concentration within the tongue of ionization gradually increases from 07:00 UT to 08:10 UT, and then it increases significantly to density val- ues exceeding $\sim 10^{12} \mathrm{~m}^{-3}$. Notably, the sudden increase coincides in time with the southward transition in $B_{Z}$. The abrupt decrease in electron density at 08:26 UT marks the onset of a series of three patches. The same pattern is seen in Beam 2 located west of Beam 1, but delayed a few minutes and the forms are stretched further poleward in MLAT, consistent with the structures being frozen into a north-westerly plasma drift across the beams.

Red vectors in Fig. 2e have a west component and blue vectors have an east component. Spurious vectors indicate that our homogeneity assumption is violated. From $\sim 08: 15$ 09:15 UT in the latitude range from 70-73.5 MLAT a sequence of four flow enhancements is seen (indicated by black arrows on the time line), intercepted by regions of distorted flow (blue). As will be commented in the Discussion section, the apparent shape of the patches observed by Beam 1 and Beam 2 is affected by the different look directions and by 


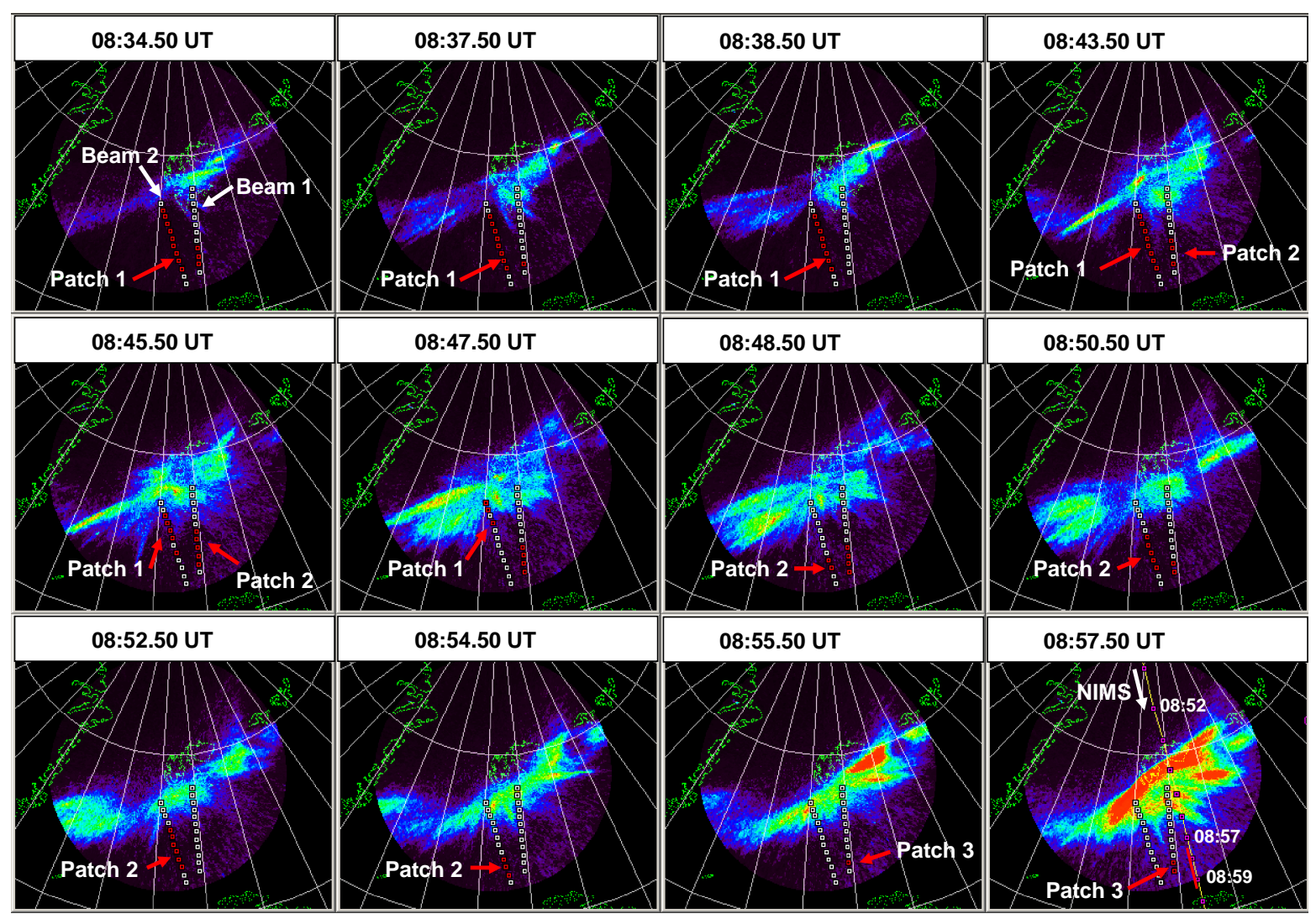

Fig. 3. A sequence of 630.0-nm images from the all-sky imager at $\mathrm{Ny}$-Ålesund. The raw images have been cut at $75^{\circ}$ zenith angle and projected onto a geographic map assuming $250 \mathrm{~km}$ as the peak emission altitude for the 630.0-nm emission of atomic oxygen $\left(\mathrm{O}^{1} \mathrm{~S}\right)$. The time is given on the top of each frame. The radar gates of the two beams of the EISCAT VHF, projected to $250 \mathrm{~km}$ altitude, are annotated in the upper left frame. Red squares mark their encounter with cold dense plasma. The yellow line superimposed on the bottom right frame depicts the ray path intersection at $350 \mathrm{~km}$ between the NIMS satellite and ground receivers.

spatial and temporal changes in the motion pattern. The cold high density plasma is located within the latitudinal range where pulsed convection bursts are seen.

Figure 3 shows a sequence of $630.0 \mathrm{~nm}$ all-sky images covering the time interval from 08:34.50-08:57.50 UT. Red squares mark the radar gates that were covered by patch densities (defined as twice the background), and the time refers to the auroral images. In the upper left image taken at 08:34.50 UT Patch 1 covers both beams simultaneously. It is essential to notice that the patch is located well equatorward of the auroral boundary, and hence it has not been exposed to particle precipitation. Comparing Figs. $2 b$ and $2 \mathrm{c}$ we see bite-outs in the high $\mathrm{T}_{e}$ associated with the highdensity plasma structures. Strong Joule heating/high $T_{i}$ in Fig. $2 \mathrm{~d}$ is observed in a region poleward of the patches, i.e. in the auroral cusp region. The patch therefore consists of cold plasma drifting in from the southeast. Between 08:37:50 and 08:38:50 UT the trailing edge of Patch 2 has disappeared from Beam 1. At 08:43:50 UT Patch 1 is still observed in Beam 2, while Patch 2 has just entered Beam 1. The plasma flow then speeds up (Fig. 2e). Patch 1 moves pole- ward along Beam 2, and at 08:47:50 UT the leading edge in Fig. 2a has entered the auroral precipitation region. At 08:48:50 UT Patch 1 has disappeared, and Patch 2 covers both beams. Patch 2 disappears from Beam 1 at 08:52:50 UT and from Beam 2 just before Patch 3 encounters Beam 1 at 08:55:50 UT. The auroral activity intensified very strongly at the time when Patch 3 entered the EISCAT field-of-view. The auroral band expanded equatorward, and Patch 3 represents the end of high density plasma drifting over the radar.

The yellow line superimposed on the bottom right image in Fig. 3 depicts the orientation of the plane of the radio tomographic image presented in Fig. 4. Electron density as a function of latitude and height is reconstructed from observed signals from the Navy Ionospheric Monitoring System (NIMS) satellite that traversed the region from north to south, crossing $75^{\circ} \mathrm{N}$ at about 08:57 UT. The radio tomography monitoring system comprises receivers at Ny-Ålesund $\left(78.9^{\circ} \mathrm{N}, 12.0^{\circ} \mathrm{E}, 76.0 \mathrm{MLAT}\right)$, Longyearbyen $\left(78.2^{\circ} \mathrm{N}, 15.3^{\circ} \mathrm{E}, 75.1 \mathrm{MLAT}\right)$, Bear Island $\left(74.5^{\circ} \mathrm{N}, 19.0^{\circ} \mathrm{E}, 71.3 \mathrm{MLAT}\right)$, and Troms $\varnothing\left(69.8^{\circ} \mathrm{N}\right.$, $\left.19.0^{\circ} \mathrm{E}, 66.6 \mathrm{MLAT}\right)$. The observations are then inverted in 
Tomographic Image: 17 Dec $2001 \quad 08: 57$ UT Electron Density x $10^{11} \mathrm{~m}^{-3}$

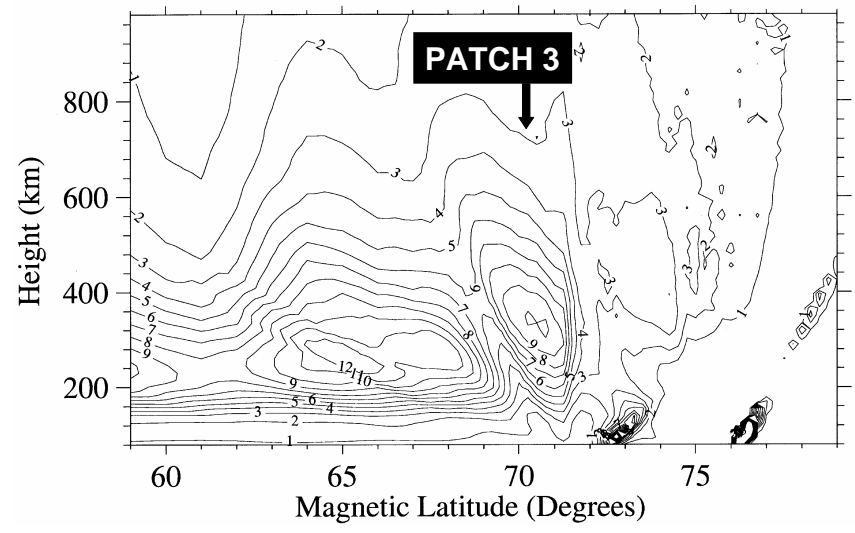

Fig. 4. A tomographic image of the electron density versus altitude and MLAT obtained along the yellow line in the bottom right image in Fig. 3, just east of the EISCAT field-of-view.

a reconstruction algorithm to create spatial images of the electron density distribution. The electron density is very small poleward of 72 MLAT. Two intensifications are seen below the $200 \mathrm{~km}$ altitude; one around 73 MLAT and another around 76.5 MLAT. Whilst some caution is necessary when interpreting the more poleward density enhancement, due to its proximity to an artifact arising from a loss of signal at the Longyearbyen receiver, it is interesting to note that the two enhancements correspond to ongoing precipitation at the two distinct regions observed along the satellite path in the bottom right image in Fig. 3. The high-density region between 69 and 72 MLAT is a cut through Patch 3, east of Beam 1. The red bar along the yellow path line marks the tomographic intersection of Patch 3 at the $350 \mathrm{~km}$ altitude. Although the F2-maximum may not be correctly positioned in altitude by tomography, the density, of the order of $10^{12} \mathrm{~m}^{-3}$, is entirely consistent with EISCAT. Equatorward of Patch 3 there is a deep minimum. The total electron content (TEC) of Patch 3 is 45 TEC units, dropping to 23 TECu immediately poleward of it. The plasma streams entering cusp latitudes reported by Foster et al. (2002, 2004a) were 2-3 times higher in TECu, but were observed using signals from GPS satellites operating at around $20000 \mathrm{~km}$ altitude. The observations reported in this paper were recorded during moderate geomagnetic conditions with a Kp level of 3, for which storm time enhanced densities (SEDs) are regularly observed in the American sector.

\section{Discussion}

The IMF $B_{Y}$ was $5 \mathrm{nT}$ or higher throughout the time of interest, with the exception of a 20-min time interval. EISCAT observed cold plasma drifting predominantly northwestward, consistent with the radar being situated under the sunward return flow in the post-noon sector (Heppner and Maynard, 1987). Figure 5 shows maps of HF backscatter recorded by the CUTLASS Finland radar from 07:00 to 07:50 UT. Of particular interest is the tongue of enhanced HF backscatter that entered the southeastern corner of the radar field-of-view and then advected poleward to connect with the cusp activity west of Svalbard around 07:38 UT. The region of strongly enhanced backscatter reached the EISCAT viewing area around 07:30 UT and is consistent with increased electron density around this time seen in Fig. 2a. From 07:34 UT onwards the morphology in the CUTLASS backscatter power indicates sub-structures in the tongue of ionization down to the north coast of Norway. The HF backscatter died out very rapidly after 07:50 UT. However, this gives a clear indication of how high density plasma entered the cusp throat.

The equatorward edge of cusp aurora is taken as a proxy for the open-closed boundary (e.g. Moen et al., 1998; Lockwood et al., 1998; Milan et al., 2003). The tomographic image presented in Fig. 4 documents that Patch 3 was fully separated from a high density region at $\sim 70$ MLAT. We therefore conclude that these plasma islands were formed on closed magnetic field lines and belong to a category of patches that is different to that of the polar cap patches that have been under investigation for more than two decades. We therefore introduce a new term, sub-auroral patches, to describe this category at subauroral latitudes.

The apparent size and shape of the patches are different in Beam 1 and Beam 2, in particular Patch 1. This may be due to slightly different look directions, spatial and temporal variability in the flow pattern, and also the shape of the patches. To investigate this further it is assumed that the patches take the shape of a sausage. Patch 1 and Patch 2 hit all radar gates between 72 and 73 MLAT almost simultaneously. Since Beam 1 is pointing toward geographic north, this is consistent with an encounter perpendicular to this beam, i.e. a motion toward geographic west that is geomagnetic northwest (cf. Fig. 2). In Beam 2 pointing towards the magnetic pole, the leading edges of all three patches are tilted towards increasing latitude with time, a right-tilt. This means a significant component of motion towards the magnetic pole along Beam 2, indicating that Beam 2 was closer to the cusp inflow region. The slope towards left (decreasing latitude with time), on the trailing edge of patches in Fig. 2b, indicates a southward component of drift in Beam 1 that actually is seen in the line-of-sight flow data (not presented). From Fig. 2 we notice that the cusp auroral boundary migrated equatorward, which indicates an expansion of the polar cap boundary. Pulses of reconnection with the intake of newly-open flux in the polar cap imply rapid boundary movements near the cusp (Lockwood et al., 1993). However, the left-tilt of the trailing edge may in part be due to a thinning of the sausage, more extended at lower latitudes. Patch 1 spent more time in Beam 2 than in Beam 1. From Fig. 2e during the passage of Patch 1 through Beam 2, we see one ion flow spurt at the 


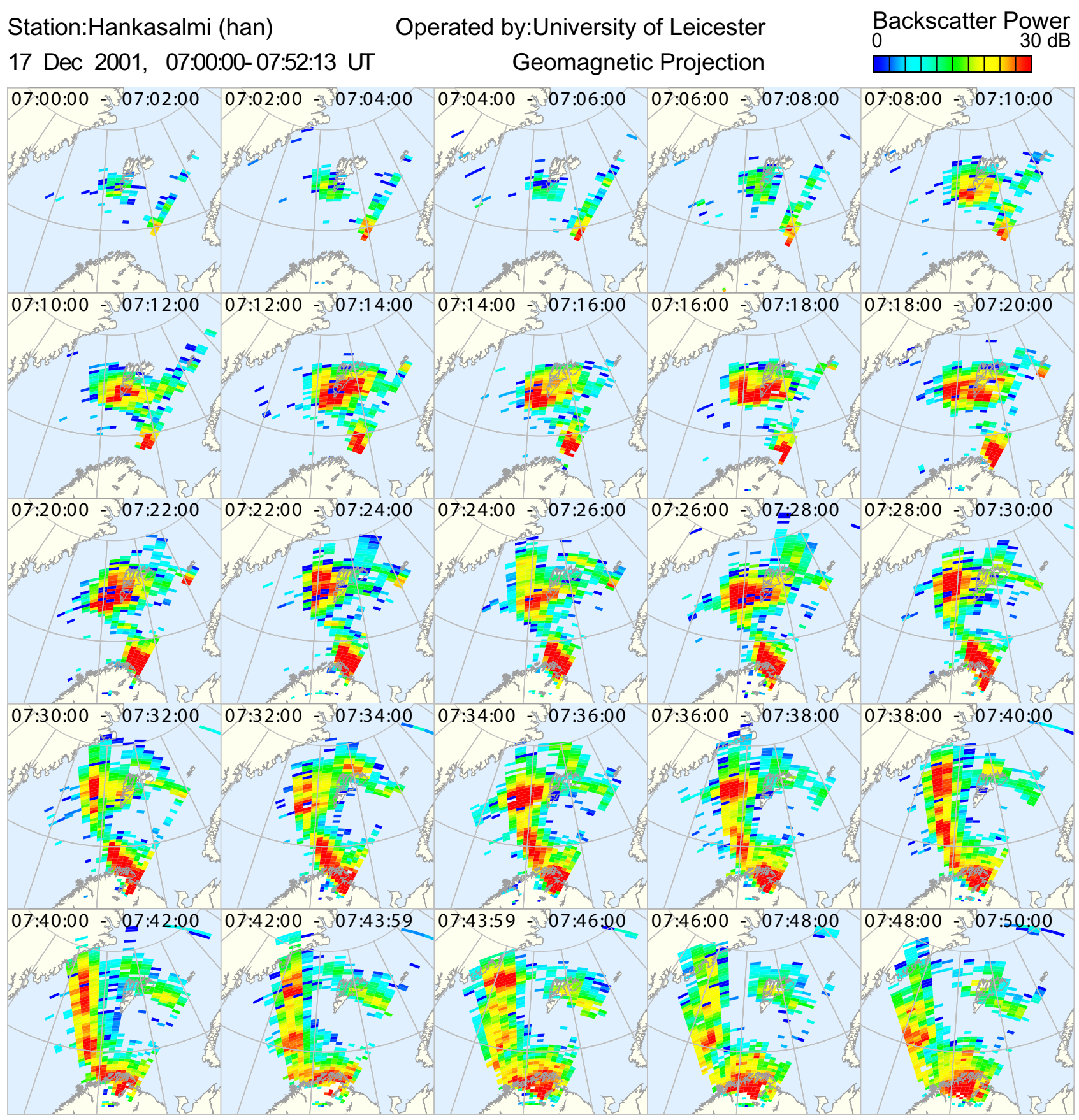

Fig. 5. Maps of HF backscatter power from the CUTLASS Finland radar from 07:00-07:50 UT. Only echoes identified to be of ionospheric origin are shown, and of particular interest is the tongue of enhanced HF backscatter power that entered the field of view from the southeastern corner.

beginning and one spurt at the end. On the top of Patch 1 in Fig. 2a, there are two forms stretching out to increasing latitudes from the patch, each associated with the onset of the above-mentioned flow spurts. In the 08:43.50 UT frame of Fig. 3 we see a thin filament of auroral brightening in the western part of the field-of-view. The flow spurt starts a couple of minutes later in Fig. 2e. This is consistent with a re- connection burst, first giving rise to an auroral flash followed by a flow enhancement a couple of minutes later, consistent with the time it takes for an Alfvén wave to transfer momentum down to the ionosphere (e.g. Moen et al., 2004; Carlson at al., 2006). The auroral phenomenon, a thin brightening arc filament with an ion flow component perpendicular to it, is a clear manifestation of plasma transport across the OCB, 
i.e. reconnection. A similar clear manifestation of magnetopause reconnection was reported by Moen et al. (2001), combining optics and the EISCAT Svalbard Radar. Patches 2 and 3 did not reach the auroral boundary during their transit time through Beam 2. This indicates a westward shift in the cusp throat between Patch 1 and Patch 2. The 20-min interval of stronger plasma drift poleward can be explained by the $\sim 20$-min interval of weak IMF $B_{Y}$. Weakening in $B_{Y}$ will introduce an eastward shift of the cusp throat. We inferred a time lag of 1 hour between ACE and the auroral response. The $B_{Y}$ explanation for the poleward elongation of Patch 1 requires a time lag of 7 additional minutes, which is not inconsistent. Reconfiguration of the flow pattern will require multiple Alfvén wave bounce times between the ionosphere and the magnetopause (Moen et al., 2004).

Due to the variability in plasma convection when the patches were in transit through the EISCAT field-of-view, it is not possible to derive an accurate estimate of the patch dimension. However, Patch 2 arrived in Beam 1 at 08:44 UT and was present for about $9 \mathrm{~min}$. The average flow velocity at an altitude of about $350 \mathrm{~km}$ between 08:47-08:52 UT, when the patch covered both radar beams was, $1.3 \mathrm{kms}^{-1}$ west and $0.3 \mathrm{kms}^{-1}$ north. Thus, assuming that the density feature moved at a constant westward speed of $1.3 \mathrm{~km} / \mathrm{s}$, its maximum longitudinal length was $700 \mathrm{~km}$. Due to the limited EISCAT field-of-view in the F2 region, the observations do not necessarily reveal the full north-south extent of the patches. However, the latitudinal extent observed in Fig. 1a and $1 \mathrm{~b}$ varied from $\sim 2-4^{\circ}$. The patch intersected by ionospheric tomography in Fig. 3 was about $300 \mathrm{~km}$ in the northsouth extent.

The patch forms reported here were fully segmented at sub-auroral cusp latitudes down to 70 MLAT. The patches presented here have many similarities with the density features observed in the same latitude region with the Chatanika radar by Foster and Doupnik (1984); however, they were not able to differentiate between polar cap and subauroral patches. Milan et al. (2002) reported sequences of patchy structures in the CUTLASS HF radar backscatter returns above Svalbard in the same time sector. Their HFbackscatter patches spanned several degrees in latitude and were similar in spatial dimension to the electron density patches reported in the current paper. However, their patch forms streamed poleward out from a band of backscatter taken as the radar signature of the auroral oval. The patch forms separated from the auroral backscatter boundary at around $\sim 75$ MLAT, which is a typical location of the cusp poleward boundary under moderate activity. Their patches belong therefore to the category of polar cap patches. However, extremely relevant to this current study were structures in HF backscatter regions that they reported at subauroral latitudes. Their observations indicated that high density plasma pulled into the cusp from sub-auroral latitudes was replaced by low density plasma from the convection return flow. Milan et al. (2002) suggested that plasma struc- turing at sub-auroral latitudes, as well as formation of polar patches, can be explained by the IMF-induced changes in the dayside convection, where plasma intake alternates between high and low density source regions. Milan et al. (2002) found their patches to be consistent with high density plasma pulled in from the south during periods dominated by $B_{Z}$ negative with the intake of lower density plasma occurring when the IMF $B_{Y}$ controlling the zonal flow component was dominating. This current study also has well-defined discontinuities in the IMF. The onset of $>10^{12} \mathrm{~m}^{-3}$ plasma coincided in time with a southward turning of IMF, but the low density regions between patches was not regulated by corresponding enhancements in $B_{Y}$, except maybe Patch 1 . As was mentioned in the above paragraph, the motion pattern of Patch 1 appeared to be influenced by IMF $B_{Y}$, and as such the minima before and after could potentially be argued from the strengthening in the $B_{Y} / B_{Z}$ ratio before and after. However, this mechanism cannot explain the formation of Patches 2 and 3 in the sequence. The segmentation must have occurred prior to their encounter into the EISCAT beams, and we therefore have no direct information about the patch segmentation. There is no indication of large $\mathrm{T}_{i}$ enhancements in the low density volumes between the patches in Fig. 2, and if the plasma depletion was due to fast flow channels / Joule heating, it must have occurred outside EISCAT is field-ofview. One key characteristic feature about the sub-auroral patch sequence is the coincidence in time with pulsed return flow, and this will be considered in more detail.

In the sub-auroral dusk, ionosphere storm enhanced density events (SEDs) move sunward towards noon (e.g. Foster, 1993; Foster et al., 2002, 2004a, 2005). The motion is driven by a sub-auroral poleward electric field associated with the low-latitude edge of the sub-auroral polarization stream (SAPS) (Foster and Burke, 2002; Foster and Vo, 2002). The SEDs form in a latitudinally narrow region near the equatorward edge of the ionospheric trough, where the sunward dusk cell convection encounters fresh co-rotating plasma (Foster, 1993). As the SED moves closer to noon, the plasma stream is exposed to a convection electric field that may be dominated by magnetopause reconnection, and which in our case is pulsed. Moen et al. (1995) documented return flow in the morning and convection cells in the afternoon that was pulsed at the same rate as optical transients, entirely consistent with the Cowley and Lockwood (1992) conceptual model for generating large-scale flow by pulsed magnetopause reconnection. The possible implication of pulsed return flow on patch formation at sub-auroral cusp latitudes is illustrated in Fig. 6 for two convection bursts. In the upper frame we assume an elongated channel of high density plasma near the co-rotating boundary. A transient flow enhancement is then generated by magnetopause reconnection. In the region of particular interest, the flow burst is equivalent to a poleward electric field $\mathbf{E}_{R}$ between an upward current sheet and a downward current sheet. Low density and high density plasma is exposed to the same electric field $\mathbf{E}_{R}$. 
The downward current sheet represents the equatorward border of the flow disturbance and is the principal component of the patch cutting mechanism. The flow decays to zero after the first patch has fully detached. In this drawing the movements of the open closed boundary have been deliberately neglected. The boundary movement represents a balance between opening of the flux at the dayside magnetopause and closure of the flux in the magnetic tail (Cowley and Lockwood, 1992; Lockwood et al., 2005a). Assuming no tail reconnection the tongue of ionization will not be pushed further toward the cusp by tail dynamics. The creation of the second patch in Fig. 6 will then require an electric field that penetrates deeper equatorward relative to the OCB than the first one. The two patches are now convecting in the same flow field.

\section{Summary and concluding remarks}

This paper has presented the first direct observation of subauroral patches. These were formed well equatorward of the ionospheric cusp and appeared like structures in the tongue of ionization. The horizontal spatial scale size of the patches was of the order of $300 \mathrm{~km} \times 700 \mathrm{~km}$, and their density was of the order of $10^{12} \mathrm{~m}^{-3}$. Had these been observed only within the polar cap, or near the cusp entry region to the polar cap, all prior work in the literature would have led inexorably to one conclusion: that their patch character (island of density at least twice that surrounding it) was derived from processes associated with the passage through the cusp into the polar cap. To the contrary here, the patch character that would have been observed later within the polar cap would have been dominated by a sub-auroral phenomenon, with the patches having segmented from a stream of high-density plasma well equatorward of the cusp precipitation region.

Milan et al. (2002) observed signatures of plasma structuring at subauroral cusp latitudes using the CUTLASS Finland Radar. At the same time they observed the formation of polar cap patches further north. They found that plasma structuring at sub-auroral latitudes, as well as in the polar cap, was controlled by IMF $B_{Y} / B_{Z}$ changes in the convection flow pattern and an alternating intake of high and low density plasma. This mechanism was not found to be applicable on the sequence of patches presented in this current paper.

The auroral cusp activity has a transient nature, and pulsed reconnection is regarded as the dominant mode of momentum transfer (Cowley and Lockwood, 1992; Moen et al., 1995). The association between a sequence of convection bursts and a sequence of patches led us to consider the potential role of transient flow at subauroral latitudes. In the case of a pulsed two-cell convection pattern, the dusk cell return flow is bounded by a downward current sheet on the equatorward side of the flow disturbance. Given that an elongated tongue of ionization is present, a patch will form when

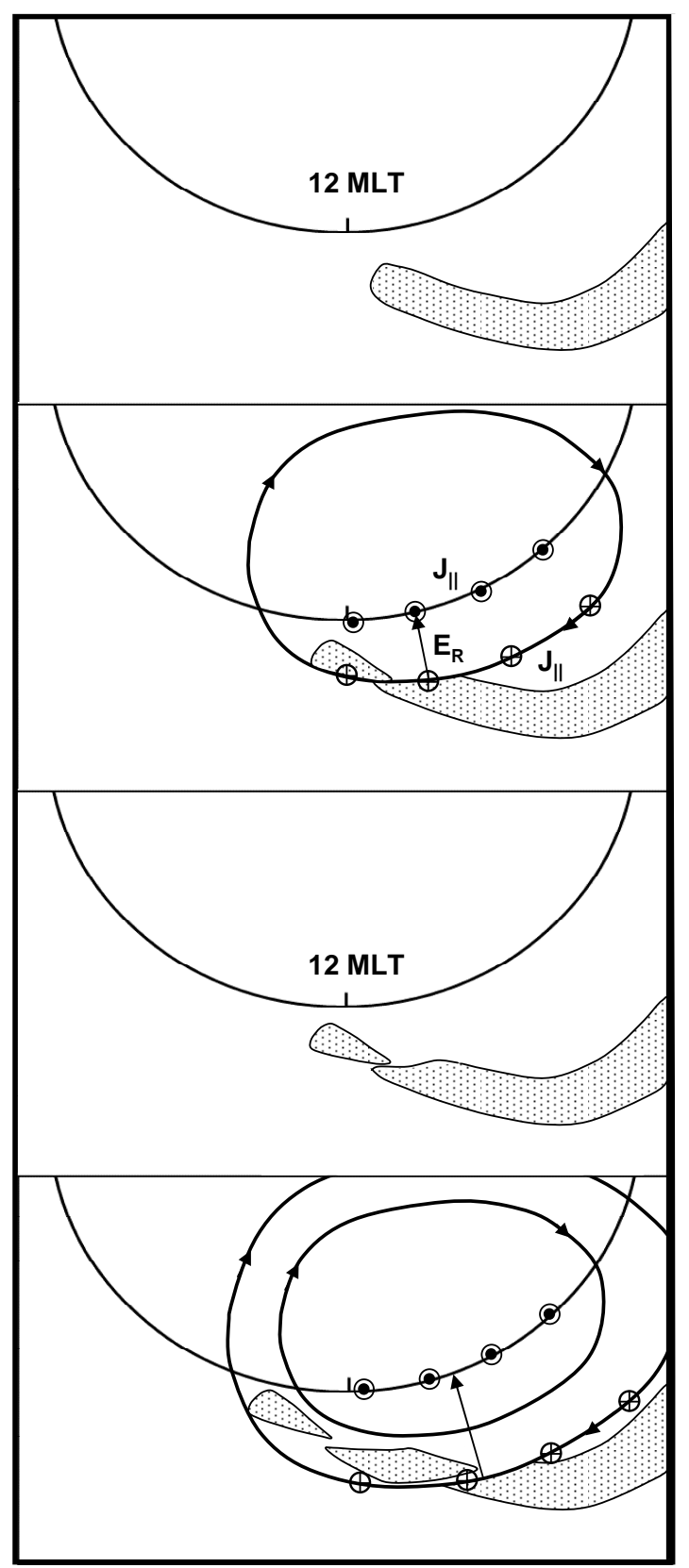

Fig. 6. Sketch of how an elongated channel of high plasma density enters the subauroral cusp region and is segmented into patches by transient changes in the sub-auroral electric field associated with a downward Birkeland current sheet.

the convection electric field maps over and hence accelerates a portion of the high density tongue. The downward Birkeland current sheet represents the physical cutting mechanism. This is similar to the idea of Anderson et al. (1988), who suggested that a discrete increase in the polar cap potential and expansion of the size of the convection pattern will bring in sunlit higher-density plasma from lower latitudes. Here we add the point that penetration of a shielding current sheet and 
the sudden increase in penetration latitude will actually segment the plasma north of the shilding current from that south of this boundary. Although related to transient reconnection, our explanation for sub-auroral patches is principally different from the Lockwood and Carlson (1992) model for polar cap patches. In their model the OCB represents the critical boundary. The sub-auroral patches will be subject to the Lockwood and Carlson (1992) model later when they are pulled across the OCB.

The tongue of ionization is normally thought of as a spatial continuous, large-scale feature of higher density plasma that stagnates in the post-noon region of strong solar production, before heading poleward into the polar cap (Foster, 1984, 1993). This may not be true because there are a few reports suggesting great variability in the SAPS electric field (e.g. Foster et al., 2004b; Oksavik et al., 2006b). Using DMSP satellite crossings of the SAPS, Mishin et al. (2003) have also found strong fluctuations in electromagnetic fields and plasma density, suggesting the presence of small-scale, fieldaligned currents that ultimately could contribute to initial segmentation of the SED. It should be pointed out that our present knowledge about structuring of sub-auroral plasma is rather limited, and that this is a phenomenon calling for more research.

Acknowledgements. EISCAT is an international association supported by Finland (SA), France (CNRS), the Federal Republic of Germany (MPG), Japan (NIPR), Norway (NFR), Sweden (NFR), and the United Kingdom (PPARC). CUTLASS is supported by the UK PPARC, the Swedish Institute for Space Physics, and the Finnish Meteorological Institute in Helsinki. The assistance of the University of Troms $\varnothing$ and the Norwegian Polar Research Institute in the tomographic measurements is gratefully acknowledged. We thank the ACE Science Center and the ACE MAG and SWEPAM instrument teams for providing solar wind data from the ACE spacecraft. Financial support has been provided by the Norwegian Research Council, AFOSR task 2311AS, UK Particle Physics and Astronomy Research Council under grant PPA/G/O/2003/00017, and NSF grant ATM-0418101.

Topical Editor M. Pinnock thanks S. Milan and an anonymous referee for their help in evaluating this paper.

\section{References}

Anderson, D. N., Buchau, J., and Heelis, R. A.: Origin of density enhancements in the winter polar cap ionosphere, Radio Sci., 23, 513-519, 1988.

Buchau, J., Reinisch, B. W., Weber, E. J., and Moore, J. G.: Structure and dynamics of the winter polar cap F-region, Radio Sci., 18, 995-1010, 1983.

Carlson, H. C., Oksavik, K., Moen, J., van Eyken, A. P., and Guio, P.: ESR mapping of polar-cap patches in the dark cusp, Geophys. Res. Lett., 29(10), 1386, doi:10.1029/2001GL014087, 2002.

Carlson, H. C., Oksavik, K., Moen, J., and Pedersen, T.: Ionospheric patch formation: Direct measurements of the origin of a polar cap patch, Geophys. Res. Lett., 31(8), L08806, doi:10.1029/2003GL018166, 2004.
Carlson, H. C., Moen, J., Oksavik, K., Nielsen, C. P., McCrea, I. W., Pedersen, T. R., and Gallop, P.: Direct observations of injection events of subauroral plasma into the polar cap, Geophys. Res. Lett., 33, L05103, doi:10.1029/2005GL025230, 2006.

Chaturvedi, P. K. and Ossakow, S. L.: The current convective instability as applied to the auroral ionosphere, J. Geophys. Res., 86, 4811-4814, 1981.

Cowley, S. W. H. and Lockwood, M.: Excitation and decay of solar wind-driven flows in the magnetosphere-ionosphere system, Ann. Geophys., 10, 103-115, 1992, http://www.ann-geophys.net/10/103/1992/.

Crowley, G.: Critical review of ionospheric patches and blobs, in: Review of Radio Science 1992-1996, edited by: Stone, W. R., Oxford University Press, UK, 619-648, 1996.

Dandekar, B. S.: Solar cycle dependence of polar cap patch activity, Radio Sci., 37(1), 1013, doi:10.1029/2000RS002562, 2002.

Dandekar, B. S. and Bullett, T. W.: Morphology of polar cap patch activity, Radio Sci., 34(5), 1187-1206, 1999.

Denig, W. F., Burke, W. J., Maynard, N. C., Rich, F. J., Jacobsen, B., Sandholt, P. E., Egeland, A., Leontjev, S., and Vorobjev, V. G.: Ionospheric signatures of dayside magnetopause transients: A case study using satellite and ground measurements, J. Geophys. Res., 98, 5969-5980, 1993.

Foster, J. C.: Ionospheric signatures of magnetospheric convection, J. Geophys. Res., 89, 855-865, 1984.

Foster, J. C.: Storm time plasma transport at middle and highlatitudes, J. Geophys. Res., 98, 1675-1689, 1993.

Foster, J. C. and Doupnik, J. R.: Plasma convection in the vicinity of the dayside cleft, J. Geophys. Res., 89, 9107-9113, 1984.

Foster, J. C. and Burke, W. J.: SAPS: A new characterization for sub-auroral electric fields, EOS, 83, 393-394, 2002.

Foster, J. C. and Vo, H. B.: Average characteristics and activity dependence of the subauroral polarization stream, J. Geophys. Res., 107 (A12), 1475, doi:10.1029/2002JA009409, 2002.

Foster, J. C., Erickson, P. J., Coster, A. J., Goldstein, J., and Rich, F. J.: Ionospheric signatures of plasmaspheric tails, Geophys. Res. Lett., 29(13), 1623, doi:10.1029/2002GL015067, 2002.

Foster, J. C., Coster, A. J., Erickson, P. J., Rich, F. J., and Sandel, B. R.: Stormtime observations of the flux of plasmaspheric ions to the dayside cusp/magnetopause, Geophys. Res. Lett., 31, L08809, doi:10.1029/2004GL020082, 2004a.

Foster, J. C., Erickson, P. J., Lind, F. D., and Rideout, W.: Millstone Hill coherent-scatter radar observations of electric field variability in the sub-auroral polarization stream, Geophys. Res. Lett., 31, L21803, doi:10.1029/2004GL021271, 2004b.

Foster, J. C., Coster, A. J., Erickson, P. J., Holt, J. M., Lind, F. D., Rideout, W., McCready, M., van Eyken, A., Barnes, R. J., Greenwald, R. A., and Rich, F.: Multiradar observations of the polar tongue of ionization, J. Geophys. Res., 110, A09S31, doi:10.1029/2004JA010928, 2005.

Heppner, J. P. and Maynard, N. C.: Empirical high-latitude electric field models, J. Geophys. Res., 92, 4467-4490, 1987.

Lockwood, M. and Carlson, H. C.: Production of polar cap electron density patches by transient magnetopause reconnection, Geophys. Res. Lett., 19, 1731-1734, 1992.

Lockwood, M., Moen, J., Cowley, S. W. H., Farmer, A. D., Løvhaug, U. P., Lühr, H., and Davda, V. N.: Variability of dayside convection and motions of the cusp/cleft aurora, Geophys. Res. Lett., 20, 1011-1014, 1993. 
Lockwood., M.: Identifying the open-closed field line boundary, in: Polar Cap Boundary Phenomena, edited by: Moen, J., Egeland, A., and Lockwood, M., NATO Advanced Study Institute Series, Kluwer Academic Press, Dordrect, Vol. 509, 415-432, 1998.

Lockwood, M., Moen, J., van Eyken, A. P., Davies, J. A., Oksavik, K., and McCrea, I. W.: Motion of the dayside polar cap boundary during substorm cycles: I. Observations of pulses in the magnetopause reconnection rate, Ann. Geophys., 23, 34953511, 2005a.

Lockwood, M., Davies, J. A., Moen, J., van Eyken, A. P., Oksavik, K., McCrea, I. W., and Lester, M.: Motion of the dayside polar cap boundary during substorm cycles: II., Generation of poleward-moving events and polar cap patches by pulses in the magnetopause reconnection rate, Ann. Geophys., 23, 35133532, 2005b.

Lorentzen, D. A., Shumilov, N., and Moen, J.: Drifting airglow patches in relation to tail reconnection, Geophys. Res. Lett., 31, L02806, doi:10.1029/2003GL017785, 2004.

McEwen, D. J. and Harris, D. P.: Observations of F-layer patches and their convection over the north magnetic-pole, Adv. Space. Res., 16 (1), 69-72, 1995.

McEwen, D. J. and Harris, D. P.: Occurrence patterns of F layer patches over the north magnetic pole, Radio Sci., 31, 619-628, 1996.

McEwen, D. J., Harris, D. P., MacDougall, J. W., and Grant, I. F.: Drifting F-layer patches over the magnetic pole, J. Geomagn. Geoelectr., 47, 527-537, 1995.

McEwen, D. J., Guo, W., MacDougall, J. W., and Jayachandran, P. T.: The polar ionosphere, Adv. Space Res., 34 (9), 2080-2084, 2004.

Milan, S. E., Lester, M., Cowley, S. W. H., Moen, J., Sandholt, P. E., and Owen, C. J.: Meridian-scanning photometer observations of the cusp: a case study, Ann. Geophys., 17, 159-172, 1999, http://www.ann-geophys.net/17/159/1999/.

Milan, S. E., Lester, M., and Yeoman, T. K.: HF radar polar patch formation revisited: summer and winter variations in dayside plasma structuring, Ann. Geophys., 20, 487-499, 2002, http://www.ann-geophys.net/20/487/2002/.

Milan, S. E., Lester, M., Cowley, S. W. H., Oksavik, K., Brittnacher, M., Greenwald, R. A., Sofko, G., and Villain, J.-P.: Variations in the polar cap area during two substorm cycles, Ann. Geophys., 21, 1121-1140, 2003, http://www.ann-geophys.net/21/1121/2003/.

Milan, S. E., Basu, S., Yeoman, T. K., Sheehan, R. E.: A comparison of satellite scintillation measurements with $\mathrm{HF}$ radar backscatter characteristics, Ann. Geophys., 23, 3451-3455, 2005 , http://www.ann-geophys.net/23/3451/2005/.

Mishin, E. V., Burke, W. J., Huang, C. Y., and Rich, F. J.: Electromagnetic wave structures within subauroral polarization streams, J. Geophys. Res., 108(A8), 1309, doi:10.1029/2002JA009793, 2003.

Moen, J., Sandholt, P. E., Lockwood, M., Denig, W. F., Løvhaug, U. P., Lybekk, B., Egeland, A., Opsvik, D., and Friis-Christensen, E.: Events of enhanced convection and related dayside auroral activity, J. Geophys. Res., 100, 23 917-23 934, 1995.

Moen, J., Lorentzen, D. A., and Sigernes, F.: Dayside moving auroral forms and bursty proton auroral events in relation to particle boundaries observed by NOAA-12, J. Geophys. Res., 103,
14 855-14 863, 1998.

Moen, J., van Eyken, A. P., and Carlson, H. C.: EISCAT Svalbard Radar observations of ionospheric plasma dynamics in relation to dayside auroral transients, J. Geophys. Res., 106, 21 453-21 461, 2001.

Moen, J., Lockwood, M., Oksavik, K., Carlson, H. C., Denig, W. F., van Eyken, A. P., and McCrea, I. W.: The dynamics and relationships of precipitation, temperature and convection boundaries in the dayside auroral ionosphere, Ann. Geophys., 22 (6), 1973 1987, 2004.

Ogawa, T., Nishitani, N., Pinnock, M., Sato, N., Yamagishi, H., and Yukimatu, A. S.: Antarctic HF radar observations of irregularities associated with polar patches and auroral blobs: A case study, J. Geophys. Res., 103, 26 547-26 558, 1998.

Oksavik, K., Moen, J., and Carlson, H. C.: High-resolution observations of the small-scale flow pattern associated with a poleward moving auroral form in the cusp, Geophys. Res. Lett., 31, L11807, doi:10.1029/2004GL019838, 2004.

Oksavik, K., Moen, J., Carlson, H. C., Greenwald, R. A., Milan, S. E., Lester, M., Denig, W. F., and Barnes, R. J.: Multi-instrument mapping of the small-scale flow dynamics related to a cusp auroral transient, Ann. Geophys., 23, 2657-2670, 2005, http://www.ann-geophys.net/23/2657/2005/.

Oksavik, K., Ruohoniemi, J. M., Greenwald, R. A., Baker, J. B. H., Moen, J., Carlson, H. C., Yeoman, T. K., and Lester, M.: Observations of isolated polar cap patches by the European Incoherent Scatter (EISCAT) Svalbard and Super Dual Auroral Radar Network (SuperDARN) Finland radars, J. Geophys. Res., 111, A05310, doi:10.1029/2005JA011400, 2006a.

Oksavik, K., Greenwald, R. A., Ruohoniemi, J. M., Hairston, M. R., Paxton, L. J., Baker, J. B. H., Gjerloev, J. W., and Barnes, R. J.: First observations of the temporal/spatial variation of the sub-auroral polarization stream from the SuperDARN Wallops HF radar, Geophys. Res. Lett., 33, L12104, doi:10.1029/2006GL026256, 2006b.

Pitout, F. and Blelly, P.: Electron density in the cusp ionosphere: increase or depletion?, Geophys. Res. Lett., 30(14), 1726, doi:10.1029/2003GL017151, 2003.

Pitout, F., Escoubet, C. P., and Lucek, E. A.: Ionospheric plasma density structures associated with magnetopause motion: a case study using the Cluster spacecraft and the EISCAT Svalbard Radar, Ann. Geophys., 22, 2369-2379, 2004, http://www.ann-geophys.net/22/2369/2004/.

Pryse, S. E., Sims, R. W., Moen, J., Kersley, L., Lorentzen, D., and Denig, W. F.: Evidence for solar-production as a source of polarcap plasma, Ann. Geophys., 22, 1093-1102, 2004, http://www.ann-geophys.net/22/1093/2004/.

Rodger, A. S. and Graham, A. C.: Diurnal and seasonal occurrence of polar cap patches, Ann. Geophys., 14, 533-537, 1996, http://www.ann-geophys.net/14/533/1996/.

Rodger, A. S., Pinnock, M., Dudeney, J. R., Baker, K. B., and Greenwald, R. A.: A new mechanism for polar patch formation, J. Geophys. Res., 99, 6425-6436, 1994.

Sandholt, P. E., Lockwood, M., Oguti, T., Cowley, S. W. H., Freeman, K. S. C., Lybekk, B., Egeland, A., and Willis, D. M.: Midday auroral breakup events and related energy and momentum transfer from the magnetosheath, J. Geophys. Res., 95, 10391060, 1990.

Sandholt, P. E., Moen, J., Rudland, A., Opsvik, D., Denig, W. F., 
and Hansen, T.: Auroral event sequences at the dayside polar cap boundary for positive and negative IMF BY, J. Geophys. Res., 98, 7737-7756, 1993.

Sandholt, P. E., Farrugia, C. J., Moen, J., Cowley, S. W. H., and Lybekk, B.: Dynamics of the aurora and associated convection currents during a cusp bifurcation event, Geophys. Res. Lett., 25, 4313-4316, 1998.

Sojka, J. J., Bowline, M. D., Schunk, R. W., Decker, D. T., Valladares, C. E., Sheehan, R., Anderson, D. N., and Heelis, R. A.: Modeling polar cap F-region patches using time varying convection, Geophys. Res. Lett., 20, 1783-1786, 1993.

Tsunoda, R. T.: High-latitude F region irregularities: A review and synthesis, Rev. Geophys., 26, 719-760, 1988.

Valladares, C. E., Basu, S., Buchau, J., and Friis-Christensen, E.: Experimental evidence for the formation and entry of patches into the polar cap, Radio Sci., 29(1), 167-194, 1994.

Valladares, C. E., Decker, D. T., Sheehan, R., and Anderson, D. N.: Modeling the formation of polar cap patches using large plasma flows, Radio Sci., 31(3), 573-594, 1996.
Valladares, C. E., Decker, D. T., Sheehan, R., Anderson, D. N., Bullett, T., and Reinisch, B. W.: Formation of polar cap patches associated with north-to-south transitions of the interplanetary magnetic field, J. Geophys. Res., 103(A7), 14 657-14 670, 1998.

Walker, I. K., Moen, J., Kersley, L., and Lorentzen, D. A.: On the possible role of cusp/cleft precipitation in the formation of polarcap patches, Ann. Geophys., 17, 1298-1305, 1999, http://www.ann-geophys.net/17/1298/1999/.

Weber, E., Buchau, J., Moore, J. G., Sharber, J. R., Livingstone, R. C., Winningham, J. C., and Reinisch, B. W.: F-layer ionisation patches in the polar cap, J. Geophys. Res., 89, 1683-1694, 1984. 